\title{
Anxiolytic-like and Anticonvulsant Effect in Adult Zebrafish (Danio rerio) through GABAergic System and Molecular Docking Study of Chalcone Derived from Natural Products
}

\author{
Jayze da Cunha Xavier ${ }^{1}$ (D), Maria Kueirislene Amâncio Ferreira ${ }^{2}$ (D), Antonio Wlisses da Silva 4 (D), \\ Jane Eire Silva Alencar de Menezes ${ }^{2}$ (D), Alexandre Magno Rodrigues Teixeira ${ }^{1}$ (D), \\ Paulo Nogueira Bandeira ${ }^{2}$ (D), Emanuelle Machado Marinho ${ }^{7(D)}$, Emmanuel Silva Marinho ${ }^{5(D)}$, \\ Márcia Machado Marinho ${ }^{\text {(D) }}$, Hélcio Silva dos Santos 1, 2, 3, *(D)
}

1 Department of Biological Chemistry, Regional University of Cariri, Crato, CE, Brazil; jayzecx@gmail.com (J.C.X.); amrteixeira@gmail.com (A.M.R.T.);

2 Ceará State University, Science and Technology Center, Postgraduate Program in Natural Sciences, Fortaleza, CE, Brazil; kueirislene@ hotmail.com (M.K.A.F.); jane.menezes@uece.br (J.E.S.A.M.);

3 Center for Exact Sciences and Technology - Chemistry Course, Vale do Acaraú University, Sobral, CE, Brazil; bandeirapn@yahoo.com.br (P.N.B.);

4 State University of Ceará, Northeaste biotechnology network, Fortaleza, Ceará, Brazil; wlissesdasilva@ hotmail.com (A.W.S.);

5 Group of Theoretical Chemistry and Electrochemistry, State University of Ceará, Limoeiro do Norte, CE, Brazil; emmanuel.marinho@uece.br (E.M.M.);

6 Faculty of Education, Science and Letters of Iguatu, State University of Ceará, Iguatu, CE, Brazil; marcia.marinho@uece.br (M.M.M.);

7 Federal University of Ceará, Department of Analytical Chemistry and Physical Chemistry, Fortaleza, CE, Brazil; emanuellemarinho@gmail.com (E.S.M.);

* Correspondence: helciodossantos@gmail.com (H.S.S.);

Received: 27.01.2021; Revised: 22.02.2021; Accepted: 25.02.2021; Published: 2.03.2021

\begin{abstract}
Anxiety and seizure are mental disorders commonly treated in the clinic with benzodiazepines (BZDs). However, long-term treatment with these drugs causes side effects such as decreased motor coordination, drowsiness, sedation, and, when used for a long time, leads to dependence and withdrawal syndromes. This study's objective was to evaluate the anxiolytic-like and anticonvulsant effect in adult zebrafish (Danio rerio) through GABAergic system of synthetic chalcone derived from cinnamaldehyde and natural acetophenone isolated from Croton anisodontus and their mechanisms of action via the Gabaergic system, using adult zebrafish. The animals were treated with chalcone $(0.1$ or 0.5 or $1.0 \mathrm{mg} / \mathrm{kg} ; 20 \mu \mathrm{L} ;$ i.p; $)$ and subjected to the open field test. The chalcone caused locomotor alteration when evaluated in the light $\&$ dark anxiolytic test. The lowest effective dose was chosen to assess possible involvement in the $\mathrm{GABA}_{\mathrm{A}}$ receptor. The chalcone showed anxiolytic and anticonvulsant effects in all doses in both tests. The chalcone presented anticonvulsant activity, a possible inhibitor of Carbonic Anhydrase and an anxiolytic effect dependent on the GABAergic system, coupling it in a different region from the diazepam inhibitor.
\end{abstract}

Keywords: cinnamaldehyde; chalcone; Zebrafish; anxiety; seizures.

(c) 2021 by the authors. This article is an open-access article distributed under the terms and conditions of the Creative Commons Attribution (CC BY) license (https://creativecommons.org/licenses/by/4.0/).

\section{Introduction}

Zebrafish (Danio rerio) is a fish found in fresh water and has been used for pharmacological investigation of new bioactive compounds. This animal's use as an 
experimental model is because it is a small animal, with easy maintenance, good reproductive rate, besides presenting a sequenced genome with $70 \%$ homology to that of the human being and anatomy of the central nervous system known. These advantages make using this model satisfactory in behavioral, toxicological, and pharmacological studies to elucidating mechanisms of several human diseases [1]. The literature points out that Zebrafish comes being used for studies of anxiety [2], seizure [3], Alzheimer's [4], inflammation [5], diabetes [6], cholesterol [7], fatty liver [8], cardiovascular disease [9, 10], oxidative stress [11] and antimicrobial and antifungal activities [12-14].

Anxiety and seizure are mental disorders commonly treated in the clinic with benzodiazepines (BZDs); these drugs were introduced into therapeutic practice more than 50 years ago due to their central nervous system depressing effects [15]. However, long-term treatment with these drugs causes side effects such as decreased motor coordination, drowsiness, sedation, and, when used for a long time, leads to dependence and withdrawal syndromes, and in high doses, they can be fatal. The anxiolytic-like effect shown by chalcones derivatives makes this class of compounds an important tool to discover new agents with increased strength, low cost, superior pharmacokinetic properties, and minimum side effects [16]. Its structure comprises at least two aromatic rings connected by an unsaturated $\alpha-\beta$ bridge, probably the most responsible for its biological activities [17-20]. They can be obtained from natural sources or by synthesis and are widely distributed in fruits, vegetables, and tea [21,22]. This compound class has aroused much interest due to the wide spectrum of pharmacological activities present, including antinociceptive, anti-inflammatory, antitumor, antibacterial, Anxiolytic, antifungal, antileishmanial, and antioxidant activity [23, 24].

This work aimed to evaluate the anxiolytic-like and anticonvulsant effect in adult zebrafish (Danio rerio) through GABAergic system of chalcone (2E, 4E)-1-(2-hydroxy-3,4,6trimethoxyphenyl)-5-phenylpenta-2,4-dien-1-one derived from cinnamaldehyde and natural acetophenone isolated from Croton anisodontus.

\section{Materials and Methods}

\subsection{Drugs and reagents.}

Diazepam (Dzp, Neo Química $\left.{ }^{\circledR}\right)$, Flumazenil (Fmz; Sandoz®), Dimethyl sulfoxide (3\% DMSO; Dynamic $®)$, Pentylenetetrazole (PTZ, Sigma-Aldrich).

\subsection{Synthesis and structural data.}

The compounds 2-hydroxy-3,4,6 trimethoxyacetophenone $(2 \mathrm{mmol})$ and cinnamaldehyde $(2 \mathrm{mmol})$ were placed in a volumetric flask $(25 \mathrm{~mL})$. Then $5 \mathrm{~mL}$ of ethanolic $\mathrm{NaOH}(50 \%)$ solution was added and mixed with stirring for $48 \mathrm{~h}$ at room temperature. The progress of the reaction was checked by TLC (n-hexane: ethylacetate, 2:1). After $48 \mathrm{~h}$ the reaction mixture was neutralized with dilute $\mathrm{HCl}(10 \%)$ and ice water added. The product was obtained as a yellow solid (yield: $35.4 \%$, m.p. $144.8-145.2^{\circ} \mathrm{C}$ ) filtered under reduced pressure, washed with cold water, and recrystallized from ethanol (Scheme 1) [25].

(2E, 4E)-1- (2-hydroxy-3,4,6-trimethoxyphenyl)-5-phenylpenta-2,4-dien-1-one (1)

Yellow solid (Yield: $35.4 \%$ ), m.p. $144.8-145.2^{\circ} \mathrm{C}$. IV (KBr, $\left.v_{\mathrm{cm}}{ }^{-1}\right)$ : $1634,1600,1588$, 1575, 1480, 1167. ${ }^{1} \mathrm{H} \mathrm{RMN}\left(\mathrm{CDCl}_{3}\right.$, ppm): 3.84 (s, $\left.\mathrm{MeO}\right) ; 3.93$ (s, $\left.\mathrm{MeO}\right) ; 3.95(\mathrm{~s}, \mathrm{MeO}) ; 6.99$ (s, H-5'); 7.44 (m, H-4); 7.38 (d, H-3/5, J = 7,1 Hz,); 7.51 (d, H-2/6, J=7,2 Hz); 7.62 (d, Ha,

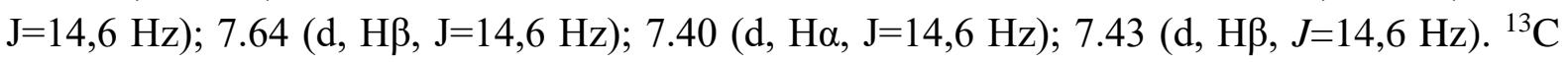


RMN (CDCl $3, \mathrm{ppm})$ : $193.2(\mathrm{C}=\mathrm{O})$; 60.9 (MeO-3'); 56.1 (MeO-4'); $56.2\left(\mathrm{MeO}-6^{\prime}\right) ; 107.0$ (C1'); 158.7 (C-2'); 131.0 (C-3'); 159.6 (C-4'); 87.2 (C-5'); 158.5 (C-6'); 136.5 (C-1); 127.7 (C2/6); 129.1 (C-3/5); $131.0(\mathrm{C}-4) ; 129.2(\mathrm{C} \alpha) ; 143.5(\mathrm{C} \beta) ; 127.0(\mathrm{C} \alpha) ; 141.8(\mathrm{C} \beta)$. MS-EI $\mathrm{m} / \mathrm{z}$ $=340)$.<smiles>COc1cc(OC)c(C(C)=O)c(OC)c1OC</smiles><smiles>COc1cc(OC)c(C(=O)/C=C/C=C/c2ccccc2)c(O)c1OC</smiles>

1

Scheme 1. Preparation of chalcone. a) $\mathrm{NaOH} 50 \% \mathrm{w} \mathrm{v}^{-1}$, ethanol, t.a., $48 \mathrm{~h}$.

\subsection{Involvement of the GABAergic system in anxiety.}

To assess the involvement of the GABAergic system in anxiolytic activity, a group of animals $(\mathrm{n}=6$ / each) received the GABAA antagonist flumazenil ( $4.0 \mathrm{mg} / \mathrm{kg}$; i.p.) 15 minutes before the chalcone cinnamaldehyde or diazepam. After $30 \mathrm{~min}$ of the treatments, the animals were submitted to the light $\&$ dark test [16].

\subsection{Pentylenetetrazole-induced seizure (PTZ).}

PTZ-induced seizure reversal was investigated $(\mathrm{n}=6 /$ group) and the animals were treated with chalcone $(0.1 ; 0.5$ and $1 \mathrm{mg} / \mathrm{mL} ; 20 \mu \mathrm{L} ;$ ip $)$, Diazepam $(1.0 \mathrm{mg} / \mathrm{mL} ; 20 \mu \mathrm{L} ;$ ip $)$, vehicle (3\% DMSO; $20 \mu \mathrm{L} ;$ ip). An untreated group ( $\mathrm{n}=6 /$ group) was included (Naive). After $30 \mathrm{~min}$, the animals were exposed to PTZ at $7.5 \mathrm{mM}$, and the behavior similar to seizure in three stages was evaluated: stage I - dramatically increased swimming activity; stage II swirling swimming behavior; stage III - clonus-like seizures, followed by loss of posture when the animal falls to one side and remains immobile for 1-3 s [26, 27]. At the end of the analysis of the 3 stages of the test, the animals were euthanized on the ice.

\subsection{Docking of the anxiolytic effect on the GABAergic system.}

For the study of molecular docking involving anxiolytic activity, the GABAA receptor was selected. Its structure was obtained from the Protein Data Bank database (https://www.rcsb.org/), identified as "CryoEM structure of human full-length alpha1beta3gamma2L GABA (A) $\mathrm{R}$ in complex with diazepam (Valium), GABA and megabody Mb38 "(PDB 6HUP), deposited with a resolution of $3.58 \AA$, determined by electron microscopy, classified as a membrane protein, Homo sapiens organism, and Homo sapiens and Escherichia coli expression system. Computer simulations were performed using the AutoDock Vina code (version 1.1.2), using 3-way multithreading, Lamarkian Genetic Algorithm [28]. The grid box was defined with parameters of $126 \AA x 100 \AA x 126 \AA$, centered on the entire protein with the dimensions $(\mathrm{x}, \mathrm{y}, \mathrm{z})=(125,281,139,534,136,018) .50$ independent simulations were carried out with 20 poses each as a standard procedure. For the selection of simulations with better poses, the simulations that presented RMSD (Root Mean Square Deviation) value less than $2 \AA$ [29] and free binding energy $(\Delta \mathrm{G})$ below $-6.0 \mathrm{kcal} / \mathrm{mol}$ were used as criteria [30]. The Discovery Studio Visualizer [31] and UCSF Chimera codes were used to analyzing the results and generate the two-dimensional chemical interaction maps [32]. 


\subsection{Docking of the anticonvulsant effect.}

For the in silico study of the potential anticonvulsant effect of chalcone, the structure of the enzyme Carbonic Anhydrase II (AC II) (PDB 3F8E) was obtained from the Protein Data Bank database (https:/www.rcsb.org/), identified as "Coumarins are a novel class of suicide carbonic anhydrase inhibitors". The protein structure is deposited in the Protein Data Bank with the co-crystallized TE1 inhibitor (coumarin), with a resolution of $2.00 \AA$, determined by XRay Diffraction, classified as lyase and Homo sapiens organism. For docking simulations, the AutoDock Vina code (version 1.1.2) was used [28]. The grid box was defined with parameters of $94 \AA x 96 \AA x 106 \AA$, centered on the whole protein with the dimensions $(x, y, z)=(-8,086$, $0,658,17,136)$, being carried out 50 independent simulations with obtaining 20 poses each. For the selection of simulations with better poses, the simulations that presented RMSD (Root Mean Square Deviation) value less than $2 \AA[29]$ and free binding energy $(\Delta \mathrm{G})$ below -6.0 $\mathrm{kcal} / \mathrm{mol}$ were used as criteria [30]. The results were analyzed and visualized using the codes Discovery Studio Visualizer [31] and UCSF Chimera [32].

\subsection{Statistical analysis.}

The zebrafish results were expressed as mean \pm standard error of the mean for in vivo tests ( $n=6 /$ group). After confirming the normality and homogeneity distribution of the data, differences between the groups were subjected to analysis of variance (one-way ANOVA), followed by the Tukey test, using the GraphPad Prism v software. 7.0. The level of statistical significance was considered to be $5 \%(\mathrm{p}<0.05)$.

\section{Results and Discussion}

\subsection{Mechanism of anxiolytic action.}

Flumazenil reduced (\#\# \# p <0.001) the anxiolytic effect of chalcone $(0.5 \mathrm{mg} / \mathrm{mL} ; 20$ $\mu \mathrm{L} ;$ ip) and Diazepam (1.0 mg / $\mathrm{mL} ; 20 \mu \mathrm{L}$; ip) (Figure 1). The anxiolytic activity of chalcone performed by Xavier et al. (2020) aroused the interest in investigating the mechanism of anxiolytic action of chalcone. Thus, we performed a light $\&$ dark test using flumazenil, a GABAA receptor antagonist. Based on Fig. 1, pretreatment with flumazenil altered the effects of chalcone $(0.5 \mathrm{mg} / \mathrm{mL} ; 20 \mu \mathrm{L} ;$ ip $)$ and Diazepam $(1.0 \mathrm{mg} / \mathrm{mL} ; 20 \mu \mathrm{L} ;$ ip $)$ in adult zebrafish, that is, it significantly reduced ( $\mathrm{p}<0.0001 \mathrm{vs.}$ Vehicle and Naive) the anxiolytic/sedative effect of the animals, indicating that the chalcone's anxiolytic activity is dependent on the GABAergic system.

\subsection{Docking of the anxiolytic effect on the GABAergic system.}

The best conformation simulation presented an RMSD of 1,746 $\AA$ and a high-affinity energy, in the order of $-8.1 \mathrm{Kcal} / \mathrm{mol}$, highlighting that the complex formed presented interactions varying between $1.98 \AA$ and $3.64 \AA$ (Table 1 ).

In order to investigate the potential anxiolytic activity of chalcone in the GABAergic system, docking simulations were carried out with the GABAA receptor, one of the most important drug targets for presenting several allosteric sites, which allow the binding of compounds with anxiolytic properties, such as benzodiazepines, modulators typically positive [33]. Regarding the interactions (Figure 2), it was possible to identify the formation of four hydrogen bonds with the $\mathrm{GABA}_{\mathrm{A}}$ receptor, three of which were classified as strong [34] with 
the LYS1191D, TYR753C, SER890C residues, and a moderate interaction with the ASP887C residue. The chalcone also presented three hydrophobic interactions with residues TYR753 and PHE772, coupling in a different region from the inhibitor Diazepam (Figure 3), a classic agonist of the GABAA receptor, thus being an indicator of a potential candidate for studies on synergism.

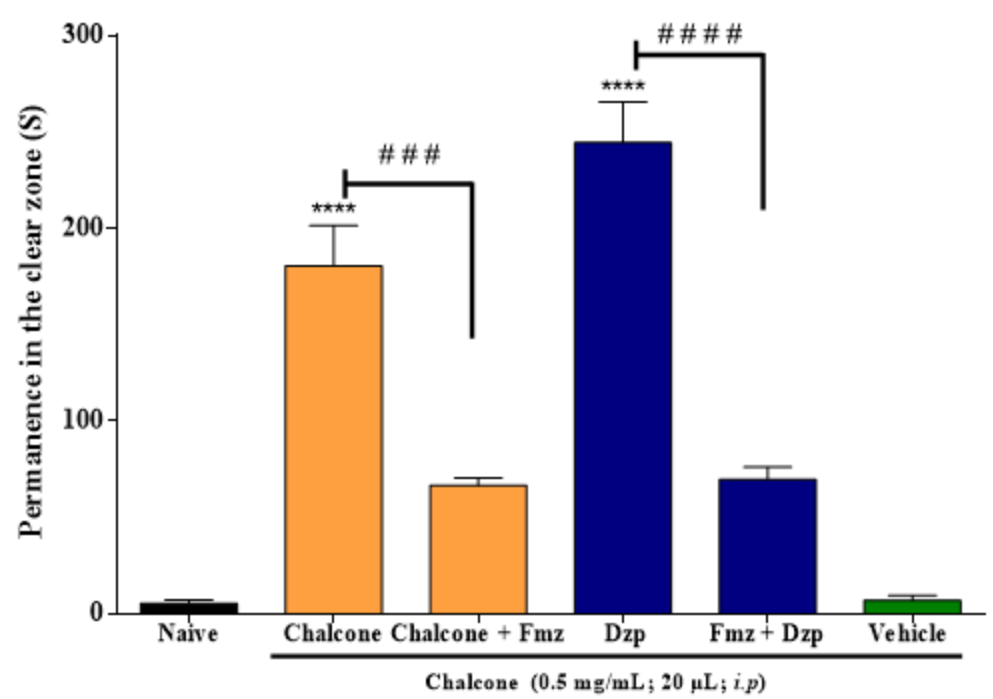

Figure 1. Effect of Flumazenil (Fmz) under the anxiolytic effect of the Chalcone - Cinnamaldehyde in the Light \& Dark Test. Chalcone - Cinnamaldehyde (0.5 mg / mL; $20 \mu \mathrm{L}$, i.p.). Dzp - Diazepam (1.0 mg / mL; $20 \mu 1$, i.p). Fmz - flumazenil $(0.1 \mathrm{mg} / \mathrm{mL} ; 20 \mu \mathrm{L}$; i.p.). The values represent the mean \pm standard error of the mean (E.P.M.) for 6 animals / group. ANOVA followed by Tukey (**** p<0.0001 vs. Naive or vehicle; ${ }^{\# \# \# ~} \mathrm{p}<0.0001 \mathrm{vs}$. Fmz + Dzp or Fmz + Chalcone).

Table 1. Interactions between the $\mathrm{GABA}_{\mathrm{A}}$ receptor and the chalcone ligand.

\begin{tabular}{l|c|c|c} 
Ligand & Receptor & Interaction & Distance $(\AA)$ \\
\hline Chalcone & TYR753C & H-Bond & $2.36 \AA$ \\
\cline { 2 - 4 } & ASP887C & H-Bond & $3.20 \AA$ \\
\cline { 2 - 4 } & SER890C & H-Bond & $2.24 \AA$ \\
\cline { 2 - 4 } & LYS1191D & H-Bond & $1.98 \AA$ \\
\cline { 2 - 4 } & TYR753C & Hydrophobic & $3.61 \AA$ \\
\cline { 2 - 4 } & PHE772C & Hydrophobic & $3.63 \AA$ \\
\cline { 2 - 4 } & PHE772C & Hydrophobic & $3.64 \AA$
\end{tabular}

\subsection{Pentylenetetrazole-induced seizure.}

The anticonvulsant effect of chalcone was evaluated through seizures induced by PTZ in adult zebrafish. Chalcone $(0.1 ; 0.5$ and $1.0 \mathrm{mg} / \mathrm{mL} ; 20 \mu \mathrm{L} ; i p)$ as well as the positive control Dzp $(1 \mathrm{mg} / \mathrm{mL} ; 20 \mu \mathrm{L} ; \mathrm{ip})$ increased latency time $(* \mathrm{p}<0.1$, ** $\mathrm{p}<0.01$, *** $\mathrm{p}<0.001$, **** $\mathrm{p}<0.0001 \mathrm{vs}$. vehicle) for the onset of PTZ-induced crises in the three stages, suggesting an anticonvulsant action (Figure 2). Pentylenetetrazole is a chemoconvulsant that acts allosterically on the GABAA receptor [35] and is used in Zebrafish to induce epileptic-like effects study seizures $[36,37]$. We evaluated the anticonvulsant effect of chalcone and Dzp on PTZ-induced seizures in adult zebrafish. Both increased the latency time for the onset of PTZinduced crises in the three stages, suggesting an anticonvulsant action (Figure 3). Antiepileptic drugs can have a sedative effect, and the treated animals show slow movements or alter locomotion [26, 27], as was demonstrated in another study carried out with chalcone cinnamaldehyde [25]; in our study, the highest doses of chalcone caused the motor impairment, which may justify its anticonvulsant action (Figure 3A). 
Flumazenil is well known as an antagonist of GABAergic receptors in $\alpha \beta \gamma$ subunits $[1-3,5]$. It antagonizes the sedative effects caused by benzodiazepine overdoses and reverses these effects in addition to preventing respiratory depression by blocking GABA receptors $[38,39]$. Thus, it is an excellent tool for the study of seizures in this receptor. We investigated the association of Diazepam and chalcone in the GABAA receptor in PTZ-induced seizures in Zebrafish (Figure 1). Our data show that pretreatment with flumazenil blocked the anticonvulsant effect of chalcone and Dzp in adult zebrafish in the three stages of the seizure (Figure 3).
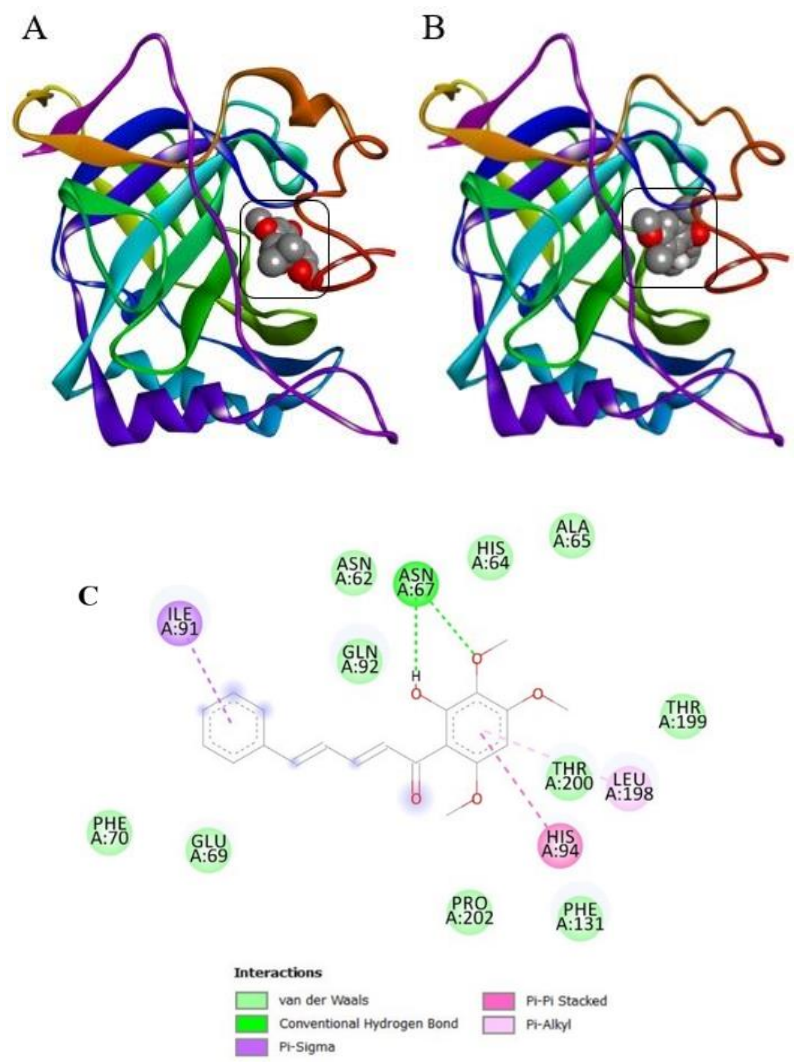

Figure 2. Interaction complex of inhibitor TE1 (A) and Chalcone (B) with the enzyme Carbonic Anhydrase II, and 2D map of interactions of the Carbonic Anhydrase II / chalcone complex (C).

\subsection{Docking of the anticonvulsant effect.}

The docking simulation between the chalcone ligand and the Carbonic Anhydrase II with better conformation presented RMSD of $1.72 \AA$ and affinity energy in the order of -5.9 $\mathrm{Kcal} / \mathrm{mol}$. The formed complex presented interactions varying between $2.38 \AA$ and $3.72 \AA$ (Table 2).

Table 2. Interactions between the enzyme Carbonic Anhydrase II and the chalcone ligand.

\begin{tabular}{l|l|l|l} 
Ligand & Receptor & Interaction & Distance (A) \\
\hline Chalcone & *ASN67A & H-Bond & $2.46 \AA$ \\
\cline { 2 - 4 } & *GLN92A & H-Bond & $2.38 \AA$ \\
\cline { 2 - 4 } & *ASN62A & H-Bond & $3.47 \AA$ \\
\cline { 2 - 4 } & *ILE91A & Hydrophobic & $3.66 \AA$ \\
\cline { 2 - 4 } & *ILE91A & Hydrophobic & $3.69 \AA$ \\
\cline { 2 - 4 } & *GLU69A & Hydrophobic & $3.68 \AA$ \\
\cline { 2 - 3 } & LEU198A & Hydrophobic & $3.69 \AA$
\end{tabular}

* Residues belonging to the catalytic site of the co-crystallized inhibitor 
For the study of the anticonvulsant effect, the enzyme Carbonic Anhydrase II was selected. Although the mechanisms that trigger seizures are not yet specifically known, $\mathrm{pH}$ changes in the brain are one of the related factors. The $\mathrm{CO}$ (2) / $\mathrm{HCO}$ (3)- buffer is the main responsible for the buffering of the intra and extracellular spaces, with the Carbonic Anhydrase enzyme responsible for the balance of the two buffer species [40]. Carbonic anhydrase inhibitors have been studied as anticonvulsant drugs in epilepsy since the 1950s [41].
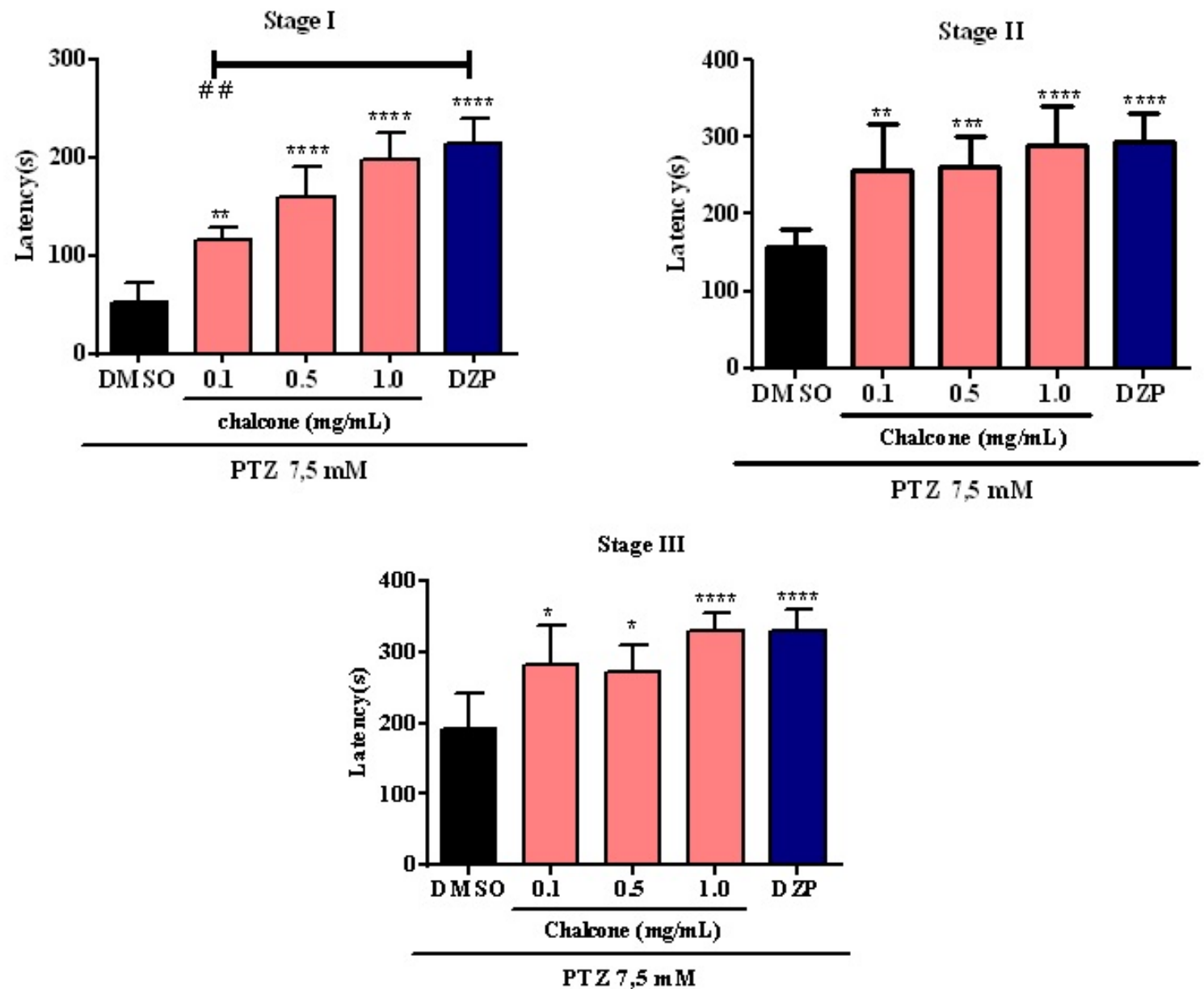

Figure 3. Effect of cinnamaldehyde chalcone on pentylenetetrazole induced seizure in adult zebrafish, stage I (A), stage II (B), stage III (C). Dzp-Diazepam (1.0 mg/mL; $20 \mu \mathrm{L} ;$ p.o.); Vehicle - 3\% DMSO (20 $\mu \mathrm{L} ;$ p.o.). The values represent the mean \pm standart error of the mean (E.P.M.) for 6 animals/group. ANOVA followed by Tukey $\left(* p<0.05, * * p<0.01, * * * p<0.001, * * * * p<0.0001\right.$ vs. Naive; ${ }^{* \#} p<0.01$ vs. Dzp).

The chalcone presents two hydrogen bonds, classified as strong [34] with residues ASN67A, GLN92A and medium intensity with residue ASN62A, being said residues belong to the catalytic site of the protein target. The AC II/chalcone complex also showed hydrophobic interactions with the ILE91A residue of the active site and GLU69A and LEU198A residues of the target protein (Figure 4). In this context, the chalcone ligand coupled in the same region as the co-crystallized inhibitor's active site (Figure 4), demonstrating a potential inhibitory effect on the carbonic anhydrase enzyme. 

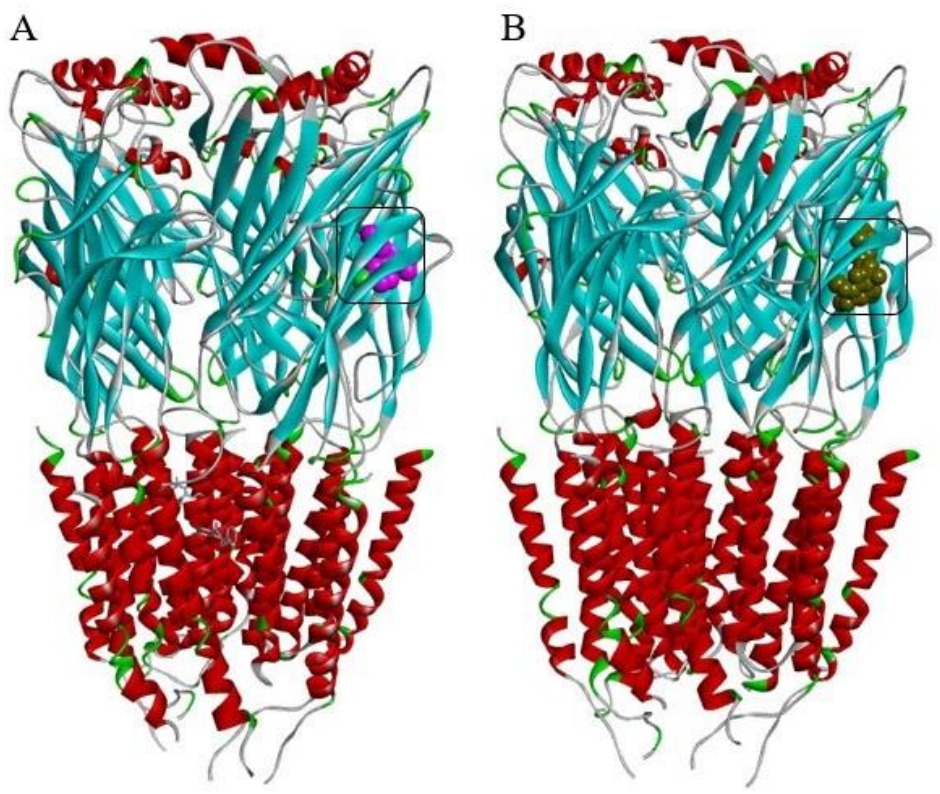

C
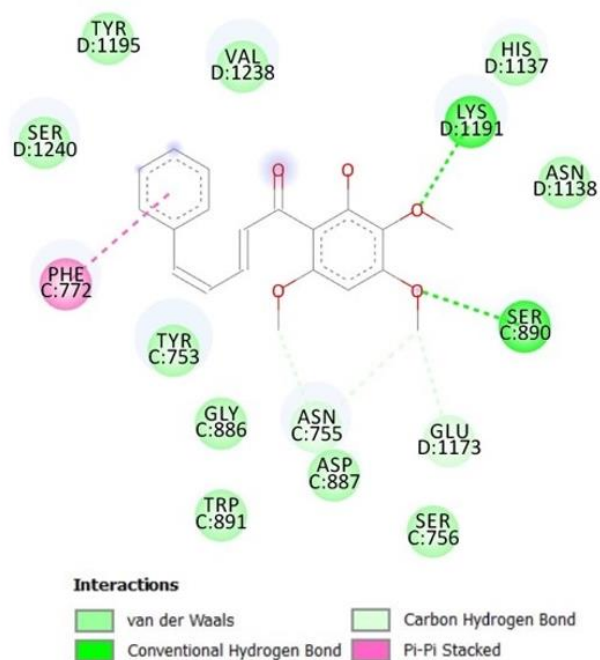

Figure 4. Diazepam (A) and Chalcone (B) interaction complex with the $\mathrm{GABA}_{\mathrm{A}}$ receptor, and $2 \mathrm{D}$ map of interactions of the $\mathrm{GABA}_{\mathrm{A}}$ / chalcone complex $(\mathrm{C})$.

\section{Conclusions}

The chalcone presented anticonvulsant activity, being a possible inhibitor of Carbonic Anhydrase and an anxiolytic effect dependent on the GABAergic system, coupling it in a different region from the diazepam inhibitor, thus being an indication of a potential candidate for studies on synergism.

\section{Funding}

This research was funded by PQ/BPI-FUNCAP (Grant\#: BP4-0172-00075.01.00/20) and CNPq (Grant: 305719/2018-1).

\section{Acknowledgments}

The authors thank FUNCAP, CAPES, CNPq, and CENAUREMN - Centro Nordestino de Aplicação e Uso da Ressonância Magnética Nuclear. 


\section{Conflicts of Interest}

The authors declare no conflict of interest.

\section{References}

1. Silva, F.C.O.; de Menezes, J.E.S.A.; Ferreira, M.K.A.; da Silva, A.W.; Holanda, C.L.A.; dos Reis Lima, J.; Campos, A.R.; Evaristo, F.F.V.; Teixeira, E.H.; Magalhães, F.E.A.; Bandeira, P.N.; dos Santos, H.S.

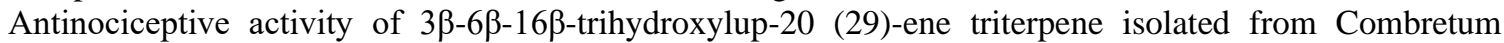
leprosum leaves in adult zebrafish (Danio rerio). Biochemical and Biophysical Research Communications 2020, 533, 362-367, https://doi.org/10.1016/j.bbrc.2020.07.107.

2. Ferreira, M.K.A.; da Silva, A.W.; Silva, F.C.O.; Vieira Neto, A.E.; Campos, A.R.; Alves Rodrigues Santos, S.A.; Rodrigues Teixeira, A.M.; da Cunha Xavier, J.; Bandeira, P.N.; Sampaio Nogueira, C.E.; de Brito, D.H.A.; Rebouças, E.L.; Magalhães, F.E.A.; de Menezes, J.E.S.A.; dos Santos, H.S. Anxiolytic-like effect of chalcone $\mathrm{N}$ - $\{4$ ' [(2E)-3-(3-nitrophenyl)-1-(phenyl)prop-2-en-1-one] $\}$ acetamide on adult zebrafish (Danio rerio): Involvement of the 5-HT system. Biochemical and Biophysical Research Communications 2020, 526, 505-511, https://doi.org/10.1016/j.bbrc.2020.03.129.

3. Siebel, A.M.; Menezes, F.P.; Capiotti, K.M.; Kist, L.W.; Schaefer, I.d.C.; Frantz, J.Z.; Bogo, M.R.; Da Silva, R.S.; Bonan, C.D. Role of Adenosine Signaling on Pentylenetetrazole-Induced Seizures in Zebrafish. Zebrafish 2015, 12, 127-136, https://doi.org/10.1089/zeb.2014.1004.

4. Saleem, S.; Kannan, R.R. Zebrafish: an emerging real-time model system to study Alzheimer's disease and neurospecific drug discovery. Cell Death Discovery 2018, 4, https://doi.org/10.1038/s41420-018-0109-7.

5. Brugman, S. The zebrafish as a model to study intestinal inflammation. Developmental \& Comparative Immunology 2016, 64, 82-92, https://doi.org/10.1016/j.dci.2016.02.020.

6. Zang, L.; Maddison, L.A.; Chen, W. Zebrafish as a Model for Obesity and Diabetes. Front. Cell Dev. Biol. 2018, 6, https://dx.doi.org/10.3389\%2Ffcell.2018.00091.

7. Yoon, Y.; Yoon, J.; Jang, M.-Y.; Na, Y.; Ko, Y.; Choi, J.-H.; Seok, S.H. High Cholesterol Diet Induces IL$1 \beta$ Expression in Adult but Not Larval Zebrafish. PLOS ONE 2013, 8, https://doi.org/10.1371/journal.pone.0066970.

8. Dai, W.; Wang, K.; Zheng, X.; Chen, X.; Zhang, W.; Zhang, Y.; Hou, J.; Liu, L. High fat plus high cholesterol diet lead to hepatic steatosis in zebrafish larvae: a novel model for screening anti-hepatic steatosis drugs. Nutrition \& Metabolism 2015, 12, https://doi.org/10.1186/s12986-015-0036-z.

9. Nguyen, C.T.; Lu, Q.; Wang, Y.; Chen, J.-N. Zebrafish as a model for cardiovascular development and disease. Drug Discovery Today: Disease Models 2008, 5, 135-140, https://doi.org/10.1016/j.ddmod.2009.02.003.

10. Giardoglou, P.; Beis, D. On Zebrafish Disease Models and Matters of the Heart. Biomedicines 2019, 7, https://doi.org/10.3390/biomedicines7010015.

11. Huang, X.; Li, Y.; Wang, T.; Liu, H.; Shi, J.; Zhang, X. Evaluation of the Oxidative Stress Status in Zebrafish (Danio rerio) Liver Induced by Three Typical Organic UV Filters (BP-4, PABA and PBSA). International Journal of Environmental Research and Public Health 2020, 17, https://doi.org/10.3390/ijerph17020651.

12. Chang, C.T.; Doerr, K.M.; Whipps, C.M. Antibiotic treatment of zebrafish mycobacteriosis: tolerance and efficacy of treatments with tigecycline and clarithromycin. Journal of Fish Diseases 2017, 40, 1473-1485, https://doi.org/10.1111/jfd.12619.

13. Gomes, M.C.; Mostowy, S. The Case for Modeling Human Infection in Zebrafish. Trends in Microbiology 2020, 28, 10-18, https://doi.org/10.1016/j.tim.2019.08.005.

14. Kulatunga, D.C.M.; Dananjaya, S.H.S.; Nikapitiya, C.; Kim, C.-H.; Lee, J.; De Zoysa, M. Candida albicans Infection Model in Zebrafish (Danio rerio) for Screening Anticandidal Drugs. Mycopathologia 2019, 184, 559-572, https://doi.org/10.1007/s11046-019-00378-z.

15. Kovačević, J.; Timić, T.; Tiruveedhula, V.V.; Batinić, B.; Namjoshi, O.A.; Milić, M.; Joksimović, S.; Cook, J.M.; Savić, M.M. Duration of treatment and activation of $\alpha 1$-containing GABAA receptors variably affect the level of anxiety and seizure susceptibility after diazepam withdrawal in rats. Brain Research Bulletin 2014, 104, 1-6, https://doi.org/10.1016/j.brainresbull.2014.03.002.

16. Ferreira, M.K.A.; da Silva, A.W.; Silva, F.C.O.; Holanda, C.L.A.; Barroso, S.M.; Lima, J.d.R.; Vieira Neto, A.E.; Campos, A.R.; Bandeira, P.N.; dos Santos, H.S.; de Lemos, T.L.G.; Siqueira, S.M.C.; Magalhães, F.E.A.; de Menezes, J.E.S.A. Anxiolytic-like effect of chalcone N-\{(4'-[(E)-3-(4-fluorophenyl)-1-(phenyl) prop-2-en-1-one] $\}$ acetamide on adult zebrafish (Danio rerio): Involvement of the GABAergic system. Behavioural Brain Research 2019, 374, https://doi.org/10.1016/j.bbr.2019.03.040.

17. Almeida-Neto, F.W.Q.; da Silva, L.P.; Ferreira, M.K.A.; Mendes, F.R.S.; de Castro, K.K.A.; Bandeira, P.N.; de Menezes, J.E.S.A.; dos Santos, H.S.; Monteiro, N.K.V.; Marinho, E.S.; de Lima-Neto, P. Characterization of the structural, spectroscopic, nonlinear optical, electronic properties and antioxidant activity of the N- $\{4$ '[(E)-3-(Fluorophenyl)-1-(phenyl)-prop-2-en-1-one]\}-acetamide. Journal of Molecular Structure 2020, 1220, https://doi.org/10.1016/j.molstruc.2020.128765. 
18. Silva, P.T.; Freitas, T.S.; Sena, D.M.; Bandeira, P.N.; Julião, M.S.; Marinho, E.S.; Alcanfor, A.A.; Marinho, E.M.; Lima-Neto, P.D.; Nogueira, C.E.; Coutinho, H.D.; Leal, A.L.; Barreto, H.M.; Martins, N.; Rodrigues Teixeira, A.M.; Santos, H.S. Structural, Vibrational and Electrochemical Analysis and Antibacterial Potential of Isomeric Chalcones Derived from Natural Acetophenone. Applied Sciences 2020, 10, https://doi.org/10.3390/app10144713.

19. Silva, P.T.; Lopes, L.M.A.; Xavier, J.C.; Carvalho , M.C.S.; Moraes, M.O.; Pessoa, C.; Barros, F.W.A.; Bandeira, P.N.; Cavalcante, C.S.P.; Teixeira, A.M.R.; Fontenelle, R.O.S.; Santos, H.S. Atividade Citotóxica e Antifúngica de Chalconas Sintetizadas a partir de uma Acetofenona Natural Isolada de Croton anisodontus. Rev. Virtual Quim. 2020, 12, 712-723, https://doi.org/10.21577/1984-6835.20200057.

20. Freitas, T.S.d.; Xavier, J.d.C.; Pereira, R.L.S.; Rocha, J.E.; Muniz, D.F.; da Silva, P.T.; da Hora, J.P.; dos Santos, H.S.; Bandeira, P.N.; Nogueira, C.E.S.; Teixeira, A.M.R.; Coutinho, H.D.M. Direct antibacterial and antibiotic resistance modulatory activity of chalcones synthesized from the natural product 2-hydroxy3,4,6-trimethoxyacetophenone. FEMS Microbiology $\quad$ Letters https://doi.org/10.1093/femsle/fnaa124.

21. Ferraz, C.A.N.; Tintino, S.R.; Teixeira, A.M.R.; Bandeira, P.N.; Santos, H.S.; Cruz, B.G.; Nogueira, C.E.S.; Moura, T.F.; Pereira, R.L.S.; Sena, D.M.; Freitas, T.S.; Rocha, J.E.; Coutinho, H.D.M. Potentiation of antibiotic activity by chalcone (E)-1-(4'-aminophenyl)-3-(furan-2-yl)-prop-2-en-1-one against gram-positive and gram-negative MDR strains. Microbial Pathogenesis 2020, 148, https://doi.org/10.1016/j.micpath.2020.104453.

22. da Silva, P.T.; da Cunha Xavier, J.; Freitas, T.S.; Oliveira, M.M.; Coutinho, H.D.M.; Leal, A.L.A.B.; Barreto, H.M.; Bandeira, P.N.; Nogueira, C.E.S.; Sena, D.M.; Almeida-Neto, F.W.Q.; Marinho, E.S.; Santos, H.S.; Teixeira, A.M.R. Synthesis, spectroscopic characterization and antibacterial evaluation by chalcones derived of acetophenone isolated from Croton anisodontus Müll.Arg. Journal of Molecular Structure 2021, 1226, https://doi.org/10.1016/j.molstruc.2020.129403.

23. Teixeira, A.M.R.; Santos, H.S.; Bandeira, P.N.; Julião, M.S.S.; Freire, P.T.C.; Lima, V.N.; Cruz, B.G.; da Silva, P.T.; Coutinho, H.D.M.; Sena, D.M. Structural, spectroscopic and microbiological characterization of the chalcone 2E-1-(2'-hydroxy-3',4',6'-trimethoxyphenyl)-3-(phenyl)-prop-2-en-1-one derived from the natural product 2-hydroxy-3,4,6-trimethoxyacetophenone. Journal of Molecular Structure 2019, 1179, https://doi.org/10.1016/j.molstruc.2018.11.075.

24. Bandeira, P.N.; Fontenelle, R.O.S.; Costa, P.S.; Santos, H.S.; Lemos, T.L.G. Atividade Antifúngica In Vitro Contra Trychophyton Rubrum de P-Aminochalcones e 3'-Metoxi-4'-Hidroxi Chalcona. Rev. Virtual Quim. 2020, 12, 703-711.

25. Xavier, J.d.C.; Almeida-Neto, F.W.Q.; da Silva, P.T.; Marinho, E.S.; Ferreira, M.K.A.; Magalhães, F.E.A.; Nogueira, C.E.S.; Bandeira, P.N.; de Menezes, J.E.S.A.; Teixeira, A.M.R.; Santos, H.S.d. Structural characterization, electronic properties, and anxiolytic-like effect in adult zebrafish (Danio rerio) of cinnamaldehyde chalcone. J. Mol. Struct. 2020, 1222, https://doi.org/10.1016/j.molstruc.2020.128954.

26. Afrikanova, T.; Serruys, A.-S.K.; Buenafe, O.E.M.; Clinckers, R.; Smolders, I.; de Witte, P.A.M.; Crawford, A.D.; Esguerra, C.V. Validation of the Zebrafish Pentylenetetrazol Seizure Model: Locomotor versus Electrographic Responses to Antiepileptic Drugs. PLOS ONE 2013, 8, https://doi.org/10.1371/journal.pone.0054166.

27. Torres-Hernández, B.A.; Del Valle-Mojica, L.M.; Ortíz, J.G. Valerenic acid and Valeriana officinalis extracts delay onset of Pentylenetetrazole (PTZ)-Induced seizures in adult Danio rerio (Zebrafish). BMC Complementary and Alternative Medicine 2015, 15, https://doi.org/10.1186/s12906-015-0731-3.

28. Trott, O.; Olson, A.J. AutoDock Vina: Improving the speed and accuracy of docking with a new scoring function, efficient optimization, and multithreading. J. Comput. Chem. 2010, 31, 455-461, https://doi.org/10.1002/jcc.21334.

29. Yusuf, D.; Davis, A.M.; Kleywegt, G.J.; Schmitt, S. An Alternative Method for the Evaluation of Docking Performance: RSR vs RMSD, J. Chem. Inf. Model. 2008, 48, 1411-1422, https://doi.org/10.1021/ci800084x.

30. Shityakov, S.; Förster, C. In silico predictive model to determine vector-mediated transport properties for the blood-brain barrier choline transporter, Adv Appl Bioinform Chem. 2014, 7, 23-36, https://doi.org/10.2147/AABC.S63749.

31. Biovia, D.S. Discovery Studio Visualizer, Dassault Systemes. BIOVIA Corp., San Diego, CA, USA, 2017.

32. Pettersen, E.F.; Goddard, T.D.; Huang, C.C.; Couch, G.S.; Greenblatt, D.M.; Meng, E.C.; Ferrin, T.E. UCSF Chimera-A visualization system for exploratory research and analysis. J. Comput. Chem. 2004, 25, 16051612, https://doi.org/10.1002/jcc.20084.

33. Masiulis, S.; Desai, R.; Uchański, T.; Martin, I.S.; Laverty, D.; Karia, D.; Malinauskas, T.; Zivanov, J.; Pardon, E.; Kotecha, A.; Steyaert, J.; Miller, K.W.; Aricescu, A.R. Author Correction: GABAA receptor signalling mechanisms revealed by structural pharmacology. Nature 2019, 566, E8-E8, https://doi.org/10.1038/s41586-019-0929-5.

34. Imberty, A.; Hardman, K.D.; Carver, J.P.; Perez, S. Molecular modelling of protein-carbohydrate interactions. Docking of monosaccharides in the binding site of concanavalin A. Glycobiology 1991, 1, 631642, https://doi.org/10.1093/glycob/1.6.631. 
35. Shaikh, M.F.; Sancheti, J.; Sathaye, S. Effect of Eclipta alba on acute seizure models: A GABAA-mediated effect. Indian J. Pharm. Sci. 2013, 75, 380-384.

36. Akbar, M.; Egli, M.; Cho, Y.-E.; Song, B.-J.; Noronha, A. Medications for alcohol use disorders: An overview. Pharmacol. Ther. 2018, 185, 64-85, https://doi.org/10.1016/j.pharmthera.2017.11.007.

37. Diniz, T.C.; de Oliveira Júnior, R.G.; Miranda Bezerra Medeiros, M.A.; Gama e Silva, M.; de Andrade Teles, R.B.; dos Passos Menezes, P.; de Sousa, B.M.H.; Abrahão Frank, L.; de Souza Araújo, A.A.; Russo Serafini, M.; Stanisçuaski Guterres, S.; Pereira Nunes, C.E.; Salvador, M.J.; da Silva Almeida, J.R.G. Anticonvulsant, sedative, anxiolytic and antidepressant activities of the essential oil of Annona vepretorum in mice: Involvement of GABAergic and serotonergic systems. Biomed. Pharmacother. 2019, 111, 10741087, https://doi.org/10.1016/j.biopha.2018.12.114.

38. Olsen, R.W.; Sieghart, W. GABAA receptors: Subtypes provide diversity of function and pharmacology. Neuropharmacology 2009, 56, 141-148, https://doi.org/10.1016/j.neuropharm.2008.07.045.

39. Penninga, E.I.; Graudal, N.; Ladekarl, M.B.; Jürgens, G. Adverse Events Associated with Flumazenil Treatment for the Management of Suspected Benzodiazepine Intoxication - A Systematic Review with Meta-Analyses of Randomised Trials. Basic Clin. Pharmacol. Toxicol. 2016, 118, 37-44, https://doi.org/10.1111/bcpt.12434.

40. Thiry, A.; Dogné, J.M.; Supuran, C.T.; Masereel, B. Carbonic Anhydrase Inhibitors as Anticonvulsant Agents. Curr. Top. Med. Chem. 2007, 7, 855-864, http://dx.doi.org/10.2174/156802607780636726.

41. Thiry, A.; Dogné, J.-M.; Supuran, C.T.; Masereel, B. Drug Design of Carbonic Anhydrase Inhibitors as Anticonvulsant Agents. In Drug Design of Zinc-Enzyme Inhibitors, 2009; pp. 171-191, https://doi.org/10.1002/9780470508169.ch7. 